\title{
Financial Factors and Corporate Governance Affecting the Sukuk Rating
}

Aditya Yoshua ${ }^{1 *}$,

Nadia Asandimitra ${ }^{2}$,

1,2 Department of Management, Faculty of Economics and Business, Universitas Negeri Surabaya, Indonesia

\begin{tabular}{|c|c|}
\hline ARTICLE INFO & ABSTRACT \\
\hline $\begin{array}{l}\text { ISSN: 2723-1097 } \\
\text { Keywords: } \\
\text { Corporate } \\
\text { Governance; Financial } \\
\text { Ratio; Firm Size; } \\
\text { Growth; Sukuk Rating }\end{array}$ & $\begin{array}{l}\text { The development of corporate sukuk in recent years has continued to show a } \\
\text { significant increase in both the number of sukuk issuers and investors of sukuk } \\
\text { instruments. This study aims to identify the determinants of financial factors and } \\
\text { corporate governance factors on the sukuk rating. The type of data used in this } \\
\text { research is quantitative data from secondary sources. The purposive sampling } \\
\text { method is used with criteria specifically non-financial companies issuing sukuk } \\
\text { circulating on the IDX and sukuk ratings were issued by PT Pefindo. The data } \\
\text { consist of } 93 \text { sukuk issuances from } 2010 \text { to 2019. Ordinal logistic regression } \\
\text { model with SPSS version } 26 \text { is then used to ascertain the significant } \\
\text { determinants of sukuk rating. This study found that financial factors such as } \\
\text { liquidity, leverage, profitability, and firm size affect the sukuk rating. However, } \\
\text { company growth does not affect the sukuk rating because the growth of company } \\
\text { assets is not followed by the growth of intangible assets such as the quality of } \\
\text { human resources. Corporate governance factors that affect the sukuk rating are } \\
\text { managerial ownership and independent commissioners. Meanwhile, the audit } \\
\text { committee does not affect the sukuk rating because the number of audit committee } \\
\text { members does not increase the company's performance. }\end{array}$ \\
\hline
\end{tabular}

\section{Introduction}

Sharia bonds or sukuk are one of the instruments for investing sharia that have been rapidly increasing over the last decade. Sukuk issuance is expected to provide alternative investment instruments for both sharia and conventional investors, broaden the base of domestic and foreign investors, and aid in the development of a sharia-based capital market. Sukuk are classified into two types based on the issuing institution: sovereign sukuk and corporate sukuk (Melis, 2017). Sovereign sukuk are issued by the government to fund the state revenue and expenditure budget as well as national development projects, whereas corporate sukuk are issued by companies to fund their own needs (Muhammad \& Biyantoro, 2019). In the corporate sukuk, there are benefits that are obtained by sukuk investors called profit sharing/fee/margin in accordance with the underlying contract. Sukuk issuers are required to repay investors' funds at maturity (Melzatia et al., 2019).

Journal of Business and Management Review Vol. 2 No. 42021 Page 272 -288

DOI: $10.47153 /$ jbmr24.1242021

*Corresponding Author

Email address: adithyoshuaoutlook@gmail.com 
In Indonesia, corporate sukuk developments continue to grow every year as the number of issuers of sukuk increases. Every year, the outstanding value of sukuk that has not been paid by the issuer increases significantly. At the end of December 2019, the total number of sukuk outstanding was 143 sukuk with an outstanding value of $\mathrm{Rp} 29.83$ trillion bringing the total number of sukuk outstanding to 232 sukuk with a total accumulated value of $\mathrm{Rp} 48.24$ trillion. This development demonstrates that the need for sharia-based investment and funding is becoming increasingly appealing to both investors and the issuer.

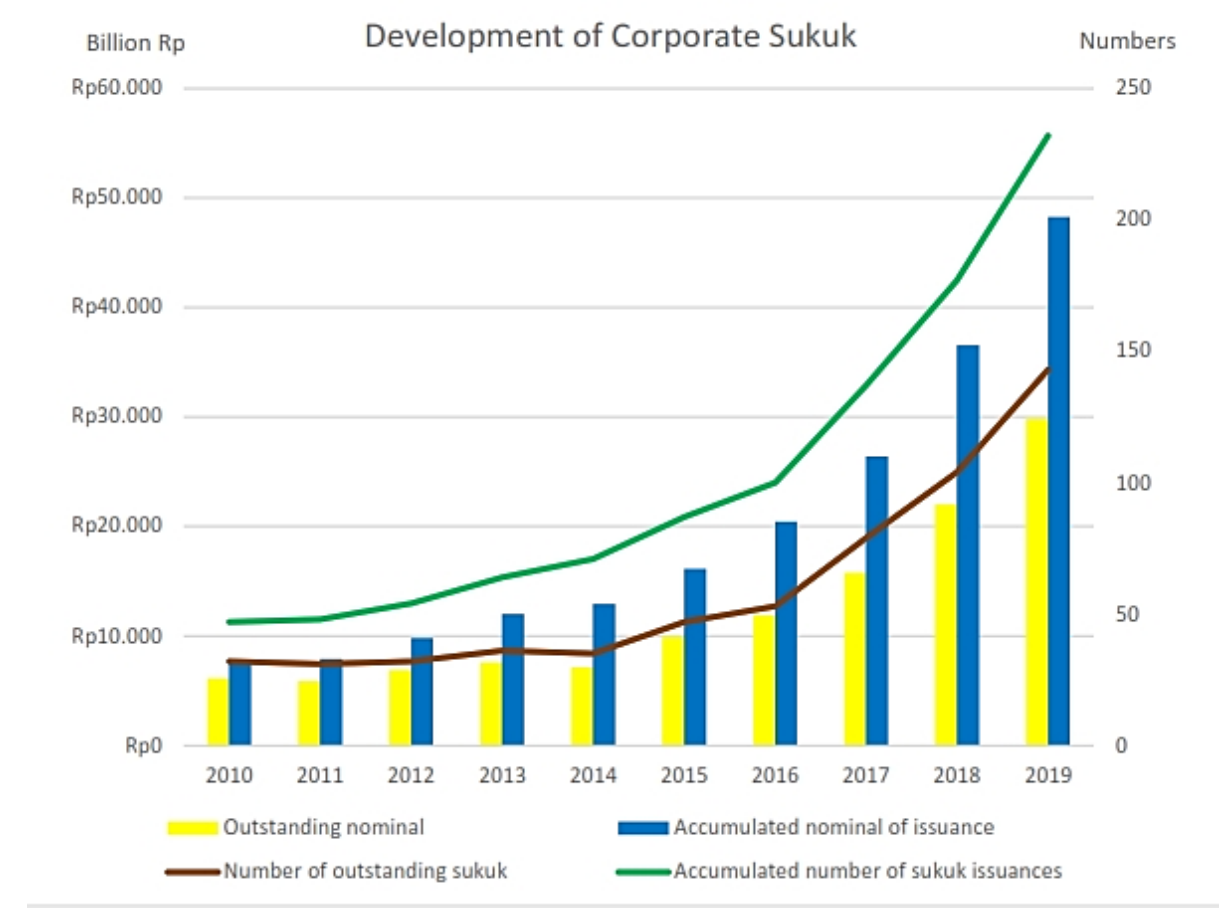

Source: Direktorat Pasar Modal Syariah - Otoritas Jasa Keuangan (2019)

Figure 1. Development of Corporate Sukuk 2010-2019

Figure 1 shows that the increase in the value of sukuk's outstanding decreased by $-4 \%$ in 2011. In 2012, there has been significant growth in the value of the sukuk's outstanding by $17.1 \%$. Then in 2013 the value of the sukuk's outstanding grew by 9.7\%. But growth fell by $-5.4 \%$ in 2014. Figure 1 also shows that in 2015 to 2019, growth in the sukuk's outstanding value began to look substantial, with an annual growth rate of $20 \%$ or more. For the $2010-2019$ period, the highest increase in the value of sukuk's outstanding was at $39.9 \%$ in 2018 . For the $2010-2019$ period, the average growth rate for the sukuk's outstanding was $20.4 \%$ a year.

A rating is contained in the sukuk instrument that informs the sukuk investors about possible risk and defaults. For the performance of sukuk and sukuk issuer, investors generally utilize information in sukuk ratings (Ningrum et al., 2020). As the sukuk rating increases, the lower the sukuk risk, and vice versa. In the event that the sukuk issuer cannot pay their liabilities at maturity, the risk in which sukuk comes is 
default risk. The sukuk rating is based on several considerations issued by a rating agency. Sukuk ratings issued by rating agencies are usually categorized into two types, namely the investment-grade category (low risk) and the non-investment grade category (high risk) (Juardi \& Sueno, 2019).

Rating agencies usually consider several internal factors such as financial factors and corporate governance when issuing sukuk ratings (Melinda \& Wardani, 2018). Based on past research, liquidity, leverage, profitability, company size and business growth include financial factors affecting the sukuk rating. In the meantime, the corporate governance that affects the sukuk rating is managerial ownership, audit committee and independent commissioners.

A high level of liquidity indicates the company's ability to pay off its obligations, which means that the risk of default (default risk) will decrease and make the rating obtained higher (Adams et al., 2003). The effect of liquidity on the sukuk rating with a positive relationship direction is supported by the results of research Afiani (2013) and Melis (2013). Meanwhile Fitriani et al. (2020) found that liquidity was able to influence the sukuk rating. Other findings by Purwaningsih (2013) and Winanti et al. (2017) stated that liquidity does not affect the sukuk rating.

A high leverage ratio shows that the company is at a high debt level, thus increasing the risk of default and reducing the rating obtained (Adams et al., 2003). The relationship of leverage to the sukuk rating in a negative direction is supported by research results by Melinda \& Wardani (2018), Ningrum et al. (2020) and Elhaj et al. (2015). However, the findings by Cahyati \& Nurnasrina (2019) show that leverage can influence the sukuk rating. Meanwhile, research by Afiani (2013), Fitriani et al. $\underline{(2020)}$ and Utami (2019) have found that sukuk ratings do not impact by the leverage ratio.

The higher the rentability, the greater the company's operational efficiency in making a profit, the lower the risk of default and the higher the rating obtained (Adams et al., 2003). Previous research by Afiani (2013), Fitriani et al. (2020), and Borhan \& Ahmad (2018) supports the impact of Profitability on the sukuk rating with a positive relationship direction. Cahyati \& Nurnasrina (2019) research has meanwhile found that profits could influence the sukuk rating. Melis (2013) and Melzatia et al. (2019) further found that profitability could not affect the rating of sukuk.

Firm size can be seen according to the company's own assets (Pranoto et al., 2017). The greater the asset, the greater the stability of the company's operating activities. A large number of assets will be used by the company to pay off its debt, reducing default risk, since the company's asset guarantee is quite large. This will increase the rating (Juardi \& Sueno, 2019). Previous research by Juardi \& Sueno (2019) and Muhammad \& Biyantoro (2019) has supported the influence of companies on sukuk's rating. Meanwhile, previous research by Utami (2019) and Pranoto et al. (2017) found that the firm size cannot affect the sukuk rating. 
Growth is a ratio in which a company can retain its position in the midst of economic and commercial conditions (Fitriani et al., 2020). The company's ability to pay off its debt will be even greater if its growth increases every year. In order to decrease the risk of default and also to increase the rate received. Research by Ningrum et al. (2020) supports the growth of companies that influence sukuk rating. Fitriani et al. (2020) and Melzatia et al. (2019) have previously indicated that the sukuk rating could not be influenced by the growth ratio.

In this case, the board and directors are directly concerned with the decisionmaking of a company, namely how much the percentage of shares owned by management (Wahidahwati, 2002). The higher the percentage of management in an undertaking, the greater the level of performance of the undertaking, because of a low conflict of interest and the better performance of management. Companies with a good performance show that the ability of the company to pay off its obligations is safeguarded and its rating improved. The effect on sukuk ratings of management ownership is supported by Prafitri and Aryani (2019) research. However, Melinda \& Wardani (2018), and Endri (2011) research show that the sukuk rating is not affected by managerial ownership.

The larger the number in the company of audit committee members, the better management control and integrity of the statements is expected to be exercised and the performance of the company will increase. This enables the company to meet its obligations and enhances its sukuk rating (Setyaningrum, 2005). The research results by Endri (2011) and Melzatia et al. (2019) support the effect of the audit committee on the sukuk assessment. Meanwhile, Prafitri \& Aryani (2019) obtained different results showing that the audit committee did not have a relationship with the sukuk rating.

An independent commissioner is a committee member who is not a member, a business, or a relative or has no relationship with the company. The growing number of independent commissioners can enhance the supervisory function of the company to become more reliable and fair and increase the company's performance to fulfill its obligations. This reduces the risk of default (default risk) and results in a high rating (Setyaningrum, 2005). Melinda \& Wardani (2018) research found that the sukuk rating was influenced by the independent commissioners. In the meantime, Endri (2011) and Prafitri \& Aryani (2019) obtained different results, with no influence on the sukuk rating among independent commissioners.

The aim of this study is to determine whether financial factors such as liquidity, leverage, profitability, firm size and growth, then corporate governance factors such as managerial ownership, audit committee, and independent commissioner affecting the sukuk rating based on the phenomena and differences in research results described. Theoretically the results of this study are expected to provide empirical evidence to companies that financial factors and corporate governance can affect the issuance of sukuk ratings by rating agencies. Practically for investors, it can be a consideration in making investment decisions by looking at the sukuk rating as a reflection of the issuer's performance. For companies that have or want to issue 
sukuk to put the financial factors and corporate governance factors affecting rating sukuk into account for expecting high rating.

\section{Literature Review}

\section{Signalling theory}

The theory of signals can be interpreted as a signal given to external parties by internal companies (Gumanti, 2009). Companies should supply interested parties with information in signal theory. Internal parties can disclose information to the rating agency in the form of financial, annual, or non-financial reports so that the rating agency later can issue bond ratings. The bond assessment can then reflect the financial situation, management performance, and the ability of the enterprise to repay its bonds (Muhammad \& Biyantoro, 2019). Incorporating a rating into bonds can signal for investors themselves to assess the extent of payment failure risk and the level of security in bonds, to reduce asymmetric information between company management and stakeholders (Melis, 2013).

\section{Agency theory}

The agency theory is based on a relationship between the agency, which can be interpreted as a relationship in which the corporate owner (principal) involves another individual (agent) (Jensen \& Meckling, 1976). Companies generally rely more on external capital injectors to finance their businesses (Nuswandari, 2009). Companies must implement corporate governance to convince third parties that the investment has been effective. Shareholders and creditors feel safe when they invest in or deal with good corporate governance companies. Good corporate governance can reduce the costs of the agency to reduce the risk of defaults. Corporate governance can be implemented through management monitoring and good information reporting, thereby reducing the presence, among internal company parties, of asymmetric information (Bhojraj \& Sengupta, 2003).

\section{Sukuk Rating}

Rating is a standard that is used to assess the worthiness of a bond. Like ratings on bonds, sukuk ratings also serve as an indication of the advantages and disadvantages of an investment instrument (Saputri \& Suprayogi, 2017). For potential investors, a sukuk rating is needed because it reflects information related to the risk and profit-sharing of the sukuk that can be considered for making investment decisions. The sukuk rating process is carried out by the rating agency. The measurement of the sukuk rating as in Melinda \& Wardani (2018) is in accordance with the definition of the sukuk rating issued by PT. Pefindo consists of superior category rating (AAA), very strong category rating ( $\mathrm{AA}+, \mathrm{AA}, \mathrm{AA}-)$, strong category rating $(\mathrm{A}+, \mathrm{A}, \mathrm{A}-)$, adequate category rating $(\mathrm{BBB}+, \mathrm{BBB}, \mathrm{BBB}-)$, and the last category rating is in the weak category $(\mathrm{BB}+, \mathrm{BB}, \mathrm{BB}-, \mathrm{B}+, \mathrm{B}, \mathrm{B}-, \mathrm{CCC}, \mathrm{D})$.

\section{Liquidity}


As regards the theory of signaling, the high degree of liquidity in the sukuk issuing company indicates that, where certain conditions are in force in the economy at any time, the company can be prepared to pay off its short-term liabilities with its current assets so as to make the risk of default decrease and give the rating agencies a signal for issuing better ratings (Adams et al., 2003). This statement is backed by the results from Afiani (2013), and Melis (2013) where the liquidity and sukuk rates have a positive relationship. Meanwhile, the research findings of Purwaningsih (2013) and Winanti et al., (2017) state that no influence exists on the sukuk rating and liquidity, as the Pefindo rating is based on quarterly financial accounts only and does not evaluate company liquidity levels in rating evaluations.

\section{Leverage}

In the signaling theory, if the leverage level in the company is high enough, this means that the company has large number of debt to increase the risk of default. The rating agency will use this signal to give a low sukuk rating as it reflects a high risk (Adams et al., 2003). Ningrum et al. (2020), Muhammad \& Biyantoro (2019), and M. Elhaj et al. (2015) support this statement. Meanwhile, the results of research by Melis (2013), Utami (2019), and Fitriani et al. (2020) stated that leverage cannot affect the sukuk rating because the rating agency does not assess leverage as the basis for granting sukuk ratings. Even though the level of debt in the company is quite large, the company is still able to allocate its debt to make a profit so that the company does not experience financial difficulties.

\section{Profitability}

In terms of profitability, the level of a company's efficiency in profit generation is evident. The higher the profitability, the higher the profitability of the company, thereby increasing the ability of the company to pay its obligations. The rating agency will capture it as a signal to give a high ranking due to the low default risk, as explained by the signal theory (Adams et al., 2003). This statement is in line with the findings of Elhaj et al. (2015) and Borhan \& Ahmad (2018). Meanwhile, the findings of Winanti et al. (2017) and Melzatia et al. (2019) found that profitability does not affect the sukuk rating because the rating agency in conducting an assessment does not only assess the profitability of an issuer, but there are several other factors according to Pranoto et al. (2017) one of them is good cash flow management. Companies that have a high level of profitability do not necessarily apply good cash flow management.

\section{Firm size}

The company's size can be an example of how large a company's assets are. The number of owned assets will have an influence on the company's stability in its operations. Companies with a large number of assets will be able to pay their debts to reduce the risk of default, which the rating agency will capture to provide high sukuk ratings on this signal as explained in the signaling theory (Juardi \& Sueno, 2019). This statement is supported by the results of research by Ningrum et al. (2020), 
Elhaj et al. (2015), and Muhammad \& Biyantoro (2019). However, this statement is not compared with Borhan \& Ahmad (2018) and Utami (2019) who found that the company's size does not affect the rating of sukuk since rating agencies are considered risk factors so that they do not evaluate company size in ratings, as companies with large assets can be bankrupted as they increase the number of their assets with liabilities.

\section{Growth}

The growth ratio which increases each period is characterized by an increase in the number of company assets and a higher payment capacity of the company. This reduces the default risk, as many assets can be used as collateral. The rating agency captures these signals as the basis for high ratings in the theory of signaling. The findings by Ningrum et al. (2020) as the previous research is supporting this statement. Meanwhile, the findings of Fitriani et al. (2020) and Melzatia et al. (2019) conclude that growth is not influenced by the sukuk rating as it may continue to grow assets every year, but this growth is not accompanied by the increase in human resources quality and good management so that the rating agency does not consider growth an indicator.

\section{Managerial Ownership}

Agency theory can explain the relationship between managerial ownership and sukuk rating, namely, if the proportion of managerial ownership in a firm is high enough, the better the performance of the company is because the risk of agency problems is diminishing as the management will further improve its performances. This shows that the company can pay off its obligations and will receive a higher sukuk rating. The findings from Prafitri \& Aryani (2019) show that managerial ownership has an influence on the sukuk rating, support this statement. However, it is not in line with the findings of Endri (2011) and Melinda \& Wardani (2018) that show managerial ownership has no effect on the sukuk rating because the percentage of managerial ownership in companies which tends to be small and does not have a significant impact is the reason rating agencies do not consider managerial ownership in rating assessment.

\section{Audit Committee}

The existence of an audit committee within the company will encourage financial reporting and the supervisory process to be more professional and reliable. As explained in agency theory, the greater the number of members of the audit committee, the better the supervision of management and the integrity of financial statements so that it is expected that the company's performance will increase. The better the company's performance will increase the company's ability to pay off its obligations so that the risk of default will decrease and the sukuk rating will be better. This is consistent with previous findings by Endri (2011) and Melzatia et al. (2019) stated that the audit committee has an effect on the sukuk rating. Meanwhile, Prafitri \& Aryani (2019) found that there is no effect of the audit committee on the 
sukuk rating because no matter how much the number of audit committees in a company will not affect the effectiveness and optimization in carrying out supervision and control, this makes the rating agency not see the audit committee as an indicator in appraisal.

\section{Independent Commissioner}

In this case, independent commissioners act autonomously without being influenced by any interest, in order to balance decision-making in the company. The increasing number of independent commissioners, as described in agency theory, can increase the management's supervisory function so that its firm performance can increase. The company will subsequently be able to pay off its obligations and decrease the risk of default. This will improve the sukuk rating. According to previous conclusions by Melinda \& Wardani (2018), the sukuk rating can be influenced by independent commissioners. Meanwhile, the independent commissioners Endri (2011) and Prafitri \& Aryani (2019) found that the sukuk rating could not be influenced by independent commissioners because the presence of the independent committee had been considered insufficient to dominate the policy adopted by all the board members and the rating agency did not consider the independent commissioners.

\section{Method}

This study was performed to determine the link or influence between independent variables: liquidity, leverage, profitability, company size, growth, management, the audit committee, and independent Commissioners on the dependent variable, namely sukuk rating. The purpose of this research is a causal associative study. In order to obtain data on sukuk and on the official website of each sample company the results of financial reports and others will be obtained via the quantitative data obtained from secondary sources, namely the PT Pefindo official website (www.pefindo.com).

The population in this study were the companies that owned sukuk that was published and circulated annually on the IDX during the 2010 to 2019 observation year. While the sample selection used the purposive sampling method with criteria including non-financial companies issuer sukuk that was published and circulated annually on the IDX from 2010 to 2019 and companies whose sukuk rating was issued by PT Pefindo from 2010 to 2019 so that a total of 93 samples were obtained. The data collection technique used is the documentation method.

With the aid of SPSS version 26, this study utilizes ordinary logistic regression analytics techniques. The method is because the dependent variable in this study uses an ordinal scale, which is an interval or ratio scale measuring the independent variables in the form of data level or ranks with categories of more than two classes. Analysis using the regular method of logistic regression does not require multivariate testing and classical assumption testing (Pentury et al., 2016). Before testing the hypothesis, the model in this study must meet the model suitability test including the data must have the same parameters, the model contained in the 
hypothesis must match the data, the model must match the empirical data, and the model must be able to explain its effects on the dependent variable.

Table 1. Operational Definition

\begin{tabular}{|c|c|c|c|}
\hline No & Variables & Measurement & Scale \\
\hline 1 & Sukuk rating & $\begin{array}{l}=\text { superior category } \\
4=\text { very strong category } \\
3=\text { strong category } \\
2=\text { adequate category } \\
1=\text { weak category }\end{array}$ & Ordinal \\
\hline 2 & Liquidity & Current Ratio & Ratio \\
\hline 3 & Leverage & Debt to Asset Ratio & Ratio \\
\hline 4 & Profitability & Return on Asset Ratio & Ratio \\
\hline 5 & Firm Size & Ln (total assets) & Ratio \\
\hline 6 & Growth & $\frac{\text { total asset }_{t}-\text { total asset }_{t-1}}{\text { total asset }_{t}}$ & Ratio \\
\hline 7 & Managerial Ownership & $\frac{\text { number of stock owned by managerial }}{\text { total of the stock }}$ & Ratio \\
\hline 8 & Audit Committee & Number of members of the audit committee & Ratio \\
\hline 9 & $\begin{array}{l}\text { Independent } \\
\text { Commissioners }\end{array}$ & $\begin{array}{l}\text { the mumber of independent commissioners } \\
\text { total members of the board of commissioners }\end{array}$ & Ratio \\
\hline
\end{tabular}

Source: (processed by author)

Result and Discussion

Table 2. Model Fit Test Result

\begin{tabular}{|c|c|c|c|c|c|}
\hline \multicolumn{2}{|c|}{ Test } & & \multirow{2}{*}{$\begin{array}{c}\begin{array}{c}-2 \text { log } \\
\text { likelihood }\end{array} \\
123,167\end{array}$} & \multirow[t]{2}{*}{ Chi-square } & \multirow[t]{2}{*}{ Sig. } \\
\hline Paralled lines & Null hypothesis & & & & \\
\hline & General & & 116,005 & 7,161 & 1,000 \\
\hline \multirow{3}{*}{$\begin{array}{l}\text { Model fitting } \\
\text { information }\end{array}$} & Intercept only & & & & \\
\hline & & & 227,096 & & \\
\hline & Final & & 123,167 & 103,930 & 0,000 \\
\hline \multirow[t]{2}{*}{ Goodness of fit } & Pearson & & & 163,630 & 1,000 \\
\hline & Deviance & & & 123,167 & 1,000 \\
\hline \multirow[t]{3}{*}{ Pseudo R square } & Cox and Snell & 0,673 & & & \\
\hline & Nagelkerke & 0,737 & & & \\
\hline & McFadden & 0,458 & & & \\
\hline
\end{tabular}

Source: Output SPSS 26 (data processed)

Paralled Lines Test 
The results of the parallel lines test in table 2 show a significance value of 1,000, which means that the model is suitable and has the same parameter category because the $\mathrm{p}$ value is $>0.05$.

\section{Model Fitting Information Test}

In table 2 the test results of the fitting model for information intercept only can be seen if the -2 log-likelihood value is 227.096 before the independent variable exists. However, the ultimate value is 123,167 after inserting the independent variables in the model. The conclusion is that the model in this study will be improved through the inclusion of independent variables including liquidity, leverage, profitability, firm size, growth, managerial ownership, audit committee and independent commissioners. A 0.00 value was also obtained in the fitting information model test, meaning that the model is fit.

\section{Goodness of Fit Test}

The test results are shown in table 2 which shows the chi-square values of Pearson and Deviance of 163.630 and 123.167 with a significance level of 1,000. So that the conclusion obtained is that the model in this study has matched the empirical data and is acceptable.

\section{Pseudo R Square (Coefficient of Determination)}

The highest value for Cox and Snell, Nagelkerke and McFadden is the Nagelkerke R-Square 0.737 in the determination coefficient test as shown in Table 2. Thus, it can be concluded that liquidity, leverage and profitability variables, firm size, growth, managerial ownership, the audit committee and independent commissioners can explain the variable of sukuk ratings by 73.7 percent, whereas other variables outside this study can explain the remaining 26.3 percent.

\section{Hypothesis Test}

Table 3. Hypothesis Test Results

\begin{tabular}{|c|c|c|c|c|}
\hline & Estimate & Std. Error & Wald & Sig. \\
\hline Threshold [rating $=1$ ] & 9,933 & 5,933 & 2,803 & 0,094 \\
\hline$[$ rating $=2]$ & 10,363 & 5,927 & 3,057 & 0,080 \\
\hline$[$ rating $=3]$ & 13,889 & 5,989 & 5,378 & 0,020 \\
\hline$[$ rating $=4]$ & 16,033 & 6,094 & 6,922 & 0,009 \\
\hline Location & $-1,178$ & 0,355 & 11,029 & 0,001 \\
\hline Leverage & $-7,161$ & 1,864 & 14,752 & 0,000 \\
\hline Profit & $-4,592$ & 1,484 & 9,574 & 0,002 \\
\hline Size & 0,690 & 0,206 & 11,235 & 0,001 \\
\hline
\end{tabular}




\begin{tabular}{ccccc} 
Growth & 0,679 & 0,982 & 0,479 & 0,489 \\
ManOwn & 9,521 & 3,699 & 6,623 & 0,010 \\
AuCom & $-0,030$ & 0,212 & 0,020 & 0,886 \\
IndComm & $-4,129$ & 1,129 & 13,384 & 0,000 \\
\hline
\end{tabular}

Source: Output SPSS 26 (data processed)

This study will be decided on in Table 3 of the results of a test of the hypothesis if the value of the wald $>Z_{0,05 / 2}(1.96)$ or the significance value $<0.05$ then the conclusion drawn is reject $H_{0}$. If the value of the wald $<Z_{0,05 / 2}$ (1.96) or the significance value $>0.05$ then the conclusion drawn is accept $H_{0}$.

The results of the variable liquidity, leverage, profitability, firm size, managerial ownership and the independent commissioners can affect the sukuk rating after the Wald tests or hypothesis testing. To ensure the following is the ordinal logistic regression model:

$$
\begin{array}{r}
\text { Negative } \log -\log \left(\mathrm{P}_{1}+\mathrm{P}_{2}+\mathrm{P}_{3}+\mathrm{P}_{4}\right)=-\log [-\log (\mathrm{x})] 16,033-1,178 \text { liquid }-7,161 \\
\operatorname{lev}-4,592 \text { profit }+0,690 \text { size }+9,521 \text { Man }-4,129 \text { IndCom }
\end{array}
$$

\section{Effect of Liquidity on Sukuk Rating}

The results of the analysis show that there is an effect on the sukuk rating with negative relationship direction between the liquidity which is supported by the current ratio in this study. This means that an enterprise with a high liquidity level is able to repay its obligations so that there is a quite low risk of default. The firm will receive a high sukuk yield in this case and vice versa. This happens because a company with a fairly high level of liquidity but a low sukuk rating is due to the accumulation of the number of current assets, thus indicating that the company is not good enough in managing its assets, especially current assets such as cash and inventories. The impact is that the level of productivity and profitability of the company is not good enough so that the level of liquidity that is too high is not too good for the company. On the other hand, even though company is not well enough to pay all of the short-term liabilities with its existing assets, the rating agency considers that as a representation that its current assets have been managed properly so that the current assets such as cash and inventories cannot be accumulated. This good governance has an impact on the company's productivity and profitability. The results of this study correspond to Fitriani et al. (2020).

\section{Effect of Leverage on Sukuk Rating}

The results of the analysis showed that the sukuk rating is negatively influenced by the leverage ratio. The lower a company's leverage, the higher the sukuk rate will be, and vice versa. That can be because the debt level of companies 
with a low leverage level is reduced to overall acquisitions, which reduces the company's risk of default and increases the company's sukuk rating. In other words, if the company has problems in its business at any time, the liabilities of the company may be paid for by its assets. Like in islamic bonds or sukuk, which apply the underlying asset principles. A high-leveraged enterprise, on the other hand, shows that the sukuk rating will be even lower if the company has a high share of its total liquidity to the total assets so that the risk of default for the company is higher. The results of this study are also supported by previous findings by Melinda \& Wardani (2018), Ningrum et al. (2020), Muhammad \& Biyantoro (2019), Winanti et al. (2017) and Elhaj et al. (2015).

\section{Effect of Profitability on Sukuk Rating}

The results of the analysis show that the level of return on assets can have a negative impact on the sukuk rating. This means that the sukuk rating is improved if the profitability of the company falls. This may be possible if the company's profitability is small because it spends a great number of funds on short- or longterm liabilities but still has enough assets to guarantee the risk of default from its sukuk. This can be done if its profitability is limited. This means that even though the percentage of net income to total assets is quite low, the risk of default faced by the company is also low because there is a guarantee of the total assets owned by the company. Although the company's profitability level is quite low, the sukuk rating it has obtained remains high. Although it is different from previous studies which found that profitability was able to positively affect the sukuk rating. However, the results in this study are in accordance with previous findings by Cahyati \& Nurnasrina (2019).

\section{Effect of Firm size on Sukuk Rating}

The results of the analysis show that the firm size can have a positive impact on the sukuk rating. That means that the larger a company's size reflects its asset numbers, the higher the company's sukuk rating. This may occur because a company with a large number of assets can guarantee all its obligations, including a maturity obligation for sukuk and periodic profit-sharing obligations for sukuk investors, thereby reducing the risk of default. Likewise, vice versa, when the company has a number of assets that are not that large, the rating agency will give a rating of sukuk that is not too good along with the increased risk of default due to reduced collateral for the company's assets. The results in this study are in line with previous findings from Juardi \& Sueno (2019), Ningrum et al. (2020), and Muhammad \& Biyantoro (2019).

\section{Effect of Growth on Sukuk Rating}

The analysis results showed that the company's growth has no impact on the sukuk rating. This result certainly differs from the one in the signage theory, where the growth of the company means that the number of the company's assets to guarantee its obligations will increase, thereby reducing the company's risk of 
default. This is the basis for the assessment of sukuk rating by the rating agency. The findings in this study show that a company with a high growth rate of assets does not go hand in hand with a growth in its intangible assets such as the quality of its human resources in order to affect the business' performance. It may be that while the growth in assets of the company has been very good, its development may be hampered by the quality of human resources and bad management in the company. This lack of intangible asset capacity makes it impossible to properly manage the assets owned by the company to ensure that asset growth, initially shown as good will, is in vain. The findings obtained this time are supported by previous studies such as Fitriani et al. (2020), Saputri \& Suprayogi (2017), and Muhammad \& Biyantoro (2019) where the rating agency does not consider the company's growth rate in the sukuk rating assessment.

\section{Effect of Managerial Ownership on Sukuk Rating}

The results of the previous analysis show that the management has an impact on sukuk rating with a positive direction. This means that the higher the percentage of managerial ownership of the issuing company, the higher the sukuk rating. This can occur because the company minimizes the possibility of agency problems and conflicts of interest between the principal and the agent, as a result of the increased percentage of management ownership. In theory of the agency it is explained that if a company minimizes the possibility of agent problems, this will affect its own performance due to the same opinions or interests that apply between the manager or agent and the owner or principle of the company. A sukuk issuing firm with good performance will be able to pay off their obligations in order to lower the risk of default and give the rating agency a high sukuk rating as well. The results in this study regarding the relationship between managerial ownership and sukuk rating support the previous findings by Prafitri \& Aryani (2019).

\section{The Effect of the Audit Committee on the Sukuk Rating}

Based on the results of the analysis previously carried out in this study, the audit committee cannot influence the sukuk rating. It does not influence the sukuk rating irrespective of the number of auditors owned by the issuing company. Because the role of the members of the audit committee itself is to help the board of directors fulfill their duties, including the maintenance of credibility in preparation of financial reports, the improvement of the supervisory role, external audits supervision and becoming a system of internal control of the company. The members of the audit committee owned in a public enterprise shall be at least 3 (three) persons. The small or high number of audit committee members has no direct effect on the company's performance, because the minimum number of audit boards, namely 3 (three) staff members, is considered sufficient to represent the tasks of the audit board, namely the performance of the tasks of the board. The results of this study support the findings of previous research by Prafitri \& Aryani (2019) where the number of members of the audit committee does not affect the sukuk rating. Companies that 
have many audit committee members will not improve the company's performance but tend to make supervision and monitoring ineffective.

\section{The Effect of the Independent Commissioners on Sukuk Rating}

Based on the results of the analysis that has been done previously, the independent commissioner is able to influence the sukuk rating with a negative influence. This means that the decreasing or smaller number of members of independent commissioners will increase the sukuk rating obtained or vice versa, the increasing number of members of independent commissioners will make the sukuk rating obtained by the company even lower. It could be due to the growing number of independent commissioners, which are external to the company and internal commissioners, who have a stake in the company, making the company's decisionmaking process more difficult due to differing views and opinions between the independent commissioners. These differences will produce decisions that will not improve the performance of the company but tend to hinder the decision-making process and thus reduce the performance of the firm, which in turn will lower the sukuk rating of the company. The results of this study also supported by the previous finding by Melinda \& Wardani (2018).

\section{Conclusion}

The conclusion that can be drawn is that liquidity, leverage, profitability, firm size, managerial ownership and independent commissioners affect the sukuk rating based on the analytical and previous discussions. The growth variable does not affect the sukuk rating, however, because the business is growing assets but is not accompanied by growth in intangible assets such as human resources quality. Even if the growth rate of the assets of the company is very good, the resource quality and management in the company does not hamper the development of the company. In the interim, the audit committee has no influence on the sukuk rating because small or large numbers of members of the audit board have no direct effect on the performance of the company, because the minimum number, namely 3 (three) members of the board of audit who are responsible for monitoring or controlling the company, is seen as sufficient as possible. Therefore, the rating agency does not take the growth of company or the number of audit committee members into account as a basis for issuing a sukuk rating.

Based on the findings in this study, namely liquidity, leverage, profitability, firm size, managerial ownership, and independent commissioners are able to influence the sukuk rating, so that these findings are expected to be a consideration for companies that have issued or will issue sukuk in order to improve these factors if they wish to obtain high sukuk rating and attracts investors to invest on their sukuk. This research also still has some limitations, such as the existence of other variables outside of this research, so that further research is needed by adding several variables such as secure, maturity, guarantee status, type of sukuk, institutional ownership, and productivity. In addition, it is hoped that further 
research can prove the effect of growth and audit committee on sukuk ratings using other measurements that are different from this study such as the growth in the number of sales for the variable growth proxy and the number of audit committee meetings in a year for the audit committee variable proxy.

\section{References}

Adams, M., Burton, B., \& Hardwick, P. (2003). The determinants of credit ratings in the United Kingdom insurance industry. Journal of Business Finance and Accounting, 30(3-4), 539-572. https:/ / doi.org/10.1111/1468-5957.00007

Afiani, D. (2013). Pengaruh Likuiditas, Produktivitas, Profitabilitas, Dan Leverage Terhadap Peringkat Sukuk. Accounting Analysis Journal, 2(1), 111-113. https:/ / doi.org/10.15294/aaj.v2i1.1151

Bhojraj, S., \& Sengupta, P. (2003). Effect of Corporate Governance on Bond Ratings and Yields: The Role of Institutional Investors and Outside Directors. Journal of Business, 76(3), 455-475. https:// doi.org/10.1086/344114

Borhan, N. A., \& Ahmad, N. (2018). Identifying the determinants of Malaysian corporate Sukuk rating. International Journal of Islamic and Middle Eastern Finance and Management, 11(3), 432-448. https:/ / doi.org/10.1108/IMEFM-02-2017-0045

Cahyati, A., \& Nurnasrina, N. (2019). Peringkat Sukuk Berdasarkan Return on Asset dan Debt to Equity Ratio. SERAMBI: Jurnal Ekonomi Manajemen Dan Bisnis Islam, 1(3), 101-110. https:/ / doi.org/10.36407/serambi.v1i3.132

Direktorat Pasar Modal Syariah - Otoritas Jasa Keuangan. (2019).

Elhaj, M. A. A., Muhamed, N. A., \& Ramli, N. M. (2015). The Influence of Corporate Governance, Financial Ratios, and Sukuk Structure on Sukuk Rating. Procedia Economics and Finance, 31(McMillen 2007), 62-74. https:/ / doi.org/10.1016/s2212-5671(15)01132-6

Endri. (2011). Corporate Governance Terhadap Peringkat Sukuk Korporasi Di Indonesia. Jurnal Keuangan Dan Perbankan, 15(2), 178-190.

Fitriani, P. R., Andriyanto, I., \& Ridwan, M. (2020). Pengaruh Rasio Keuangan dan Pertumbuhan Perusahaan Terhadap Peringkat Obligasi Syariah. AKTSAR: Jurnal Akuntansi Syariah, 3(1), 103. https:/ / doi.org/10.21043/aktsar.v3i1.7629

Gumanti, T. A. (2009). Teori Sinyal Dalam Manajemen Keuangan. Manajemen Dan Usahawan Indonesia, September, 1-29.

Jensen, M. C., \& Meckling, W. H. (1976). Theory of the Firm: Managerial Behaviour, Agency Cost and Ownership Structure. Journal of Financial Economics, 3, 305-360. https:/ / doi.org/10.1177/0018726718812602

Juardi, \& Sueno, N. (2019). Pengaruh Produktivitas , Firm Size dan Maturity Terhadap Peringkat Sukuk Pada Perusahaan Non Keuangan Di Indonesia. AKRUAL Jurnal Akuntansi Dan Keuangan, 1(2), 1-18.

Melinda, D., \& Wardani, M. K. (2018). Faktor-faktor yang mempengaruhi peringkat sukuk pada perushaan penerbit sukuk di Bursa Efek Indonesia. KOMPARTEMEN: Jurnal Ilmiah Akuntansi, 17(2), 69-90. http://jurnalnasional.ump.ac.id/index.php/kompartemen/article/view/4742

Melis. (2017). Perkembangan sukuk di Indonesia, Malaysia, dan Dunia. Economica 
Sharia, 2(2017), 72-84.

Melis, K. (2013). Analisis Faktor-Faktor Yang Mempengaruhi Rating Sukuk. Jurnal Ilmiah Mahasiswa FEB UB, 1-21.

Melzatia, S., Firdaus, R., Badaruddin, R., \& Hammat, Z. (2019). Sukuk Rating , the Involvement of Agency Theory. International Journal of Innovation, 6(8), 139-155.

Muhammad, R., \& Biyantoro, C. (2019). Faktor-Faktor Yang Mempengaruhi Peringkat Sukuk. Al - Masraf (Jurnal Lembaga Keuangan Dan Perbankan), 4(2).

Ningrum, N., Fatikhin, A., \& Darsin. (2020). Identification of the Determinant Factors of Company Sukuk Rating in Indonesia: Using Profit Management as an Intervening Variable. Proceedings of the 1st International Conference on Science, Health, Economics, Education and Technology, 27(ICoSHEET 2019), 40-43.

Nuswandari, C. (2009). Good Corporate Governance dalam Perspektif Teori Agensi. Dinamika Keuangan Dan Perbankan, 1(1), 47-53.

Pentury, T., Aulele, S. N., \& Wattimena, R. (2016). Analisis Regresi Logistik Ordinal. BAREKENG: Jurnal Ilmu Matematika Dan Terapan, 10(1), 55-60. https:/ / doi.org/10.30598/barekengvol10iss1pp55-60

Prafitri, M., \& Aryani, Y. A. (2019). Pengaruh Corporate Governance terhadap Peringkat Sukuk Perusahaan yang diperingkat oleh PEFINDO Tahun 2007-2016. Jurnal Ilmiah Ekonomi Islam, 5(3), 197-210. www.jurnal.stie-aas.ac.id > jei > article > download $\% 0 \mathrm{~A}$

Pranoto, G., Anggraini, R., \& Takidah, E. (2017). Pengaruh profitabilitas, ukuran perusahaan, produktivitas, dan reputasi auditor terhadap peringkat sukuk. Jurnal Ilmiah Wahana Akuntansi, 12(01), 13-27.

Purwaningsih, S. (2013). Faktor Yang Mempengaruhi Rating Sukuk Yang Ditinjau Dari Faktor Akuntansi dan Non Akuntansi. Accounting Analysis Journal, 2(3), 360-368.

Saputri, D., \& Suprayogi, N. (2017). Faktor-Faktor Keuangan Yang Mempengaruhi Rating Sukuk Dengan Menggunakan Model Regresi Multinomial Logistik. Jurnal Ekonomi Syariah Teori Dan Terapan, April, 436-450.

Setyaningrum, D. (2005). Pengaruh Mekanisme Corporate Governance Terhadap Peringkat Surat Utang Perusahaan Di Indonesia. Jurnal Akuntansi Dan Keuangan Indonesia, 2(2), 73-102. https:/ / doi.org/10.21002/jaki.2005.11

Utami, D. (2019). Identifying Financial and Non-Financial Factors as the Determinant of Sukuk Rating in Indonesia. Shirkah Journal Economics and Business, 4(1).

Wahidahwati. (2002). Pengaruh Kepemilikan Manajerial dan Kepemilikan Institusional pada Kebijakan Hutang Perusahaan: Sebuah Perspektif Theory Agency. Jurnal Riset Akuntansi Indonesia, 5(1), 1-16.

Winanti, E., Nurlaela, S., \& Titisari, K. (2017). Pengaruh Rasiolikuiditas, Rasio Produktivitas, Rasio Profitabilitas, Dan Rasio Solvabilitas Terhadap Peringkat Sukuk. Jurnal Akuntansi Dan Pajak, 18(01), 130-139. https:/ / doi.org/10.29040/jap.v18i01.90 
